IIUM JOURNAL OF EDUCATIONAL STUDIES, 6:1 (2018) 69-81

Copyright (1) IIUM Press

ISSN: 2289-8085

\title{
Exploring MOOC Acceptance and Readiness Among Postgraduate Students at A Higher Learning Institution
}

\author{
Mukaramatu Tahiru \\ Faculty of Education, \\ University of Malaya \\ Kuala Lumpur \\ tmukaramatu@gmail.com
}

\author{
Rosemaliza Kamalludeen \\ Kulliyyah of Education, \\ International Islamic University Malaysia \\ Kuala Lumpur \\ rosemaliza@iium.edu.my
}

\begin{abstract}
This study explores the acceptance of massive open online courses among postgraduate students in a higher learning institution in Malaysia, and their readiness to use it for learning. Acceptance in this context refers to actual use, intention to use the platform for academic purposes and their attitude towards it, while readiness refers to their knowledge of MOOCs and perceptions of its usefulness. One hundred and ninety postgraduate students responded to the survey $(\mathrm{N}=190)$. The data analysis used descriptive statistics, i.e. frequencies, percentages, means and standard deviations. The findings reveal that a majority of postgraduate students did not have knowledge of MOOCs, and very few had any actual usage of MOOCs. However, most demonstrated a positive attitude towards MOOCs and expressed an intention to use the platform for academic purposes. The findings highlighted how higher learning institutions ought to scheme policies to increase students' awareness of MOOCs and understanding of its usefulness, hence improving their acceptance and readiness to use the platform.
\end{abstract}

Keywords: Massive Open Online Courses (MOOCs), awareness knowledge, how-to knowledge, perceived usefulness, attitude, actual usage, intention to use for academic purposes, postgraduate students.

\section{INTRODUCTION}

Education has always been a classroom setting having an instructor delivering a lecture, and students on the other side listening and writing down whatever they have understood from the lecture. The traditional setting sees one-way interaction between lecturers and students as a crucial learning component. Then came the spark of the digital age. Although traditional classes are still relevant today, their existence is challenged by innovative online teaching and learning technologies (Alobiedat \& Saraierh, 2010). The field of e-learning and distant education has abruptly felt a new phenomenon with the influx of Massive Open Online Courses (MOOCs) which students and lecturers make the best use of. MOOCs are aimed to transform the processes of education. The scale of traditional courses is smaller than what MOOCs can offer due to the fact that individual participations in MOOCs are unrestricted and universally dispersed through a multiplicity of networks (Chen, Barnett \& Stephens, 2013). MOOCs are Massive Open Online 
Courses conducted by professionals in their specialised fields while learners enjoy free access to learning resources on the subjects of the courses. Neither official recognition is given for participation, nor pre-requisites are required and it is opened for free. MOOCs have gained its ground in 2012 after being introduced in 2008 (McAuley et al., 2010). As the trend today is currently gravitating towards student-centred teaching, it is extremely important for students to widen their scope of learning. MOOCs allow students to generate a virtual learning version of their field of study free of charge. The multimedia abilities of MOOCs visualize ideas and concepts clearly to permit students to relate to them accurately (Alraimi, Zo, \& Ciganek, 2015). In recent years, MOOCs have been one of the most researched areas in education. The focus of MOOCs since their inception is to offer online access to quality education for people in developed nations who are currently marginalized by existing universities and the billions of people in developing nations who have a slight hope of ever enrolling in traditional higher education (Clark, 2013). Coursera, EdX, Udacity, Udemy and Openlearning.com are the examples of the most popular websites that offer hundreds of MOOCs for their learners at no or minimal cost.

The starting point for this study was the fact that students' uptake or usage of MOOCs is essential to achieving its purpose and avoiding the problem of underutilized system. Alraimi et al. (2015) identified factors that enhance an individual's intention to continue using MOOCs and found perceived reputation, perceived openness, perceived usefulness, perceived enjoyment, and user satisfaction to have a significant influence on intention to use MOOCs. Similar observations were made by Raman (2011) who stated that the usage of technology among university students is influenced by perceived usefulness, perceived ease of use and subjective norm.

MOOCs offer lifelong learning opportunities and additional learning materials for courses in traditional settings, thus helping students to be better prepared before getting into the classroom (Seimens, 2013). Students' usage of MOOCs is motivated by several reasons such as their desire to learn about a new topic or to extend current knowledge, curiosity about MOOCs, personal experience and the desire to amass as many completion certificates as deemed necessary (Hew \& Cheung, 2014). A great advantage of MOOCs lies with their multimedia abilities which permit learners to apply concepts realistically.

\section{Statement of the Problem}

In Malaysia, students get their MOOC access at OpenLearning.com and can choose any course they want from the MOOC provider. There are heaps of courses that students can choose from and it is also convenient and easy for lecturers and instructors to manage their classes. Learning on MOOCs is a two-way communication using online text, audio and videos and offers many advantages. Many higher learning institutions in Malaysia offer several MOOCs on OpenLearning.com. Yet, Malaysian students are not aware of their deployment of MOOCs due to the lack attention given to this mode and platform of learning (Amrang, 2016; Mat-jizat et al., 2014). Moreover, there is limited literature on students' readiness to use MOOCs, that is their awareness and procedural knowledge of the platform, their actual usage of and attitude towards the courses, and intention to use them for academic purposes. This study, therefore, set to find out the answers to these questions about the acceptance of and readiness for MOOCs among postgraduate students in the context of Malaysian higher education. 


\section{Research Objectives and Questions}

This research sought to profile postgraduate students' MOOC acceptance--measured in terms of actual use, intention to use and attitude towards it--and MOOC readiness, measured in terms of their awareness and procedural knowledge of the platform and perceptions of its usefulness. Thus, the corresponding research questions were:

1. What is the extent of postgraduate students' awareness and procedural knowledge of MOOCs?

2. What are their perceptions of the usefulness of MOOCs?

3. What is their attitude towards MOOCs?

4. What is the extent of their actual use of and intention to use MOOCs for academic purposes?

\section{METHODOLOGY}

\section{Research Design}

The research employed a descriptive, cross-sectional survey design that profiled the respondents' MOOC acceptance and readiness. Descriptive statistics were used to measure and describe the following constructs of interest: (i) awareness and procedural knowledge of MOOCS; (ii) attitude towards MOOCs; (iii) perceptions of MOOCs' usefulness for learning; (iv) actual use; and (v) intention to use.

\section{Population and Sample}

The population at the time of data collection was 4,230 postgraduate students coming from six (6) faculties of a public university in Kuala Lumpur. Based on a 10\% margin of error and $95 \%$ level of confidence, the sample size should be at least 94 students. The sample of the study, therefore, exceeded these two parameters as it comprised 190 postgraduate students. They were selected from the six faculties using stratified sampling with "faculty" used as the stratum.

\section{Instrument}

A Likert questionnaire to measure the six constructs (i.e., awareness knowledge, procedural knowledge, attitude, perceived usefulness, actual use and intention to use) was developed. The items were adapted from those previously used in Davis (1989), Chen et al. (2008), Venkatesh (2000), Hu and Chau (2001), Lin and Overbaugh (2009), and Taylor and Todd (1995). The questionnaire in all contained 32 items measuring all the six constructs under study. The respondents indicated their degree of agreement and disagreement on a 5-point Likert scale with the response categories consisting of "Strongly Disagree," "Disagree," "Neutral," "Agree," and "Strongly Agree".

\section{Data Collection and Analysis}

Data were collected manually at every faculty during lecture hours after permission was granted by the respective lecturers. Students were also invited to respond to the questionnaires after class at the various lecture halls in their respective faculties. Some were met at their hostels, the library, 
and cafeterias. The Statistical Package for the Social Sciences (SPSS) version 17 software was utilised in analysing the data. The analysis procedures made use of descriptive statistics to analyse the demographic characteristics of the respondents as well as determine the means, frequencies, standard deviations and percentages of the extent of awareness knowledge, procedural knowledge of MOOCs, perceived usefulness, attitude, actual usage and intention to use MOOCs for academic purposes.

\section{RESULTS AND DISCUSSION}

The analysis of the data collected is presented in this section using descriptive statistics. A 5-point Likert scale measuring respondent agreement was used. The researcher, however, merged responses in the Strongly Disagree and Disagree categories into just one category of agreement and did the same for Agree and Strongly Agree. These are represented with the letters " $D$ " and " $A$ " respectively while neutral was represented by the letter " $N$ ". Reports of the analysis are presented in the subsequent paragraphs.

\section{Respondents' Profile}

The sample consisted of 190 postgraduate students, most of whom were female $(58.9 \% ; \mathrm{n}=112)$. Male students made up $41.1 \%(n=78)$. In terms of age, a majority were in the 25-29 age group $(44.7 \% ; \mathrm{n}=85)$. Local Malaysian students constituted $53.7 \%(\mathrm{n}=102)$; the rest were international $(46.3 \% ; \mathrm{n}=88)$. A large percentage of the respondents was students doing a master's degree $(72 \% ; \mathrm{n}$ $=137)$, while doctoral students constituted roughly $28 \%(\mathrm{n}=53)$. In terms of year of study, a majority of the respondents were in their $1^{\text {st }}$ year $(42.1 \% ; n=80)$, followed by respondents in their $2^{\text {nd }}$ year with $38.4 \%(\mathrm{n}=73)$. The least number of respondents were in their $4^{\text {th }}$ year and above, making up about $4.7 \%(n=9)$ and $2.1 \%(n=4)$ of the sample. In terms of faculty, most respondents were from the faculty of Islamic Revealed Knowledge and Human Sciences $(22.6 \%$; $n=43)$, followed by Engineering $(20.5 \% ; \mathrm{n}=39)$. Law students constituted the smallest percentage $(11.6 \% ; \mathrm{n}=22)$.

\section{Internet Access and Use}

About half of the respondents could only get access to the Internet on campus $(46.8 \% ; \mathrm{n}=89)$. The rest were able to get both on and off campus access $(43.7 \% ; \mathrm{n}=83)$. Only about $9.5 \%(\mathrm{n}=$ 18 ) said they could not get any access if they were not on campus. Most respondents were laptop users $(65.3 \% ; n=124)$ who accessed the Internet from their laptops via the campus' wireless connection. Close to $29 \%(\mathrm{n}=55)$ used laptops and mobile devices, while only about $1.6 \%(\mathrm{n}=$ 3) used PCs as points of Internet connection.

In terms of use, $56.3 \%(\mathrm{n}=107)$ used the Internet both in and out of class. Ninety-one percent $(91 \% ; \mathrm{n}=172)$ used it for academic purposes, social media purposes and seeking information. Only $6.3 \%(\mathrm{n}=12)$ reported a rather strict use of it, accessing the Internet only for academic purposes. About $1 \%(n=2)$ used it only for social media. 


\section{Awareness Knowledge of MOOCs}

Frequencies and percentages were used to determine the extent of the respondents' level of awareness of MOOCs. The results are presented in Figure 1 below.

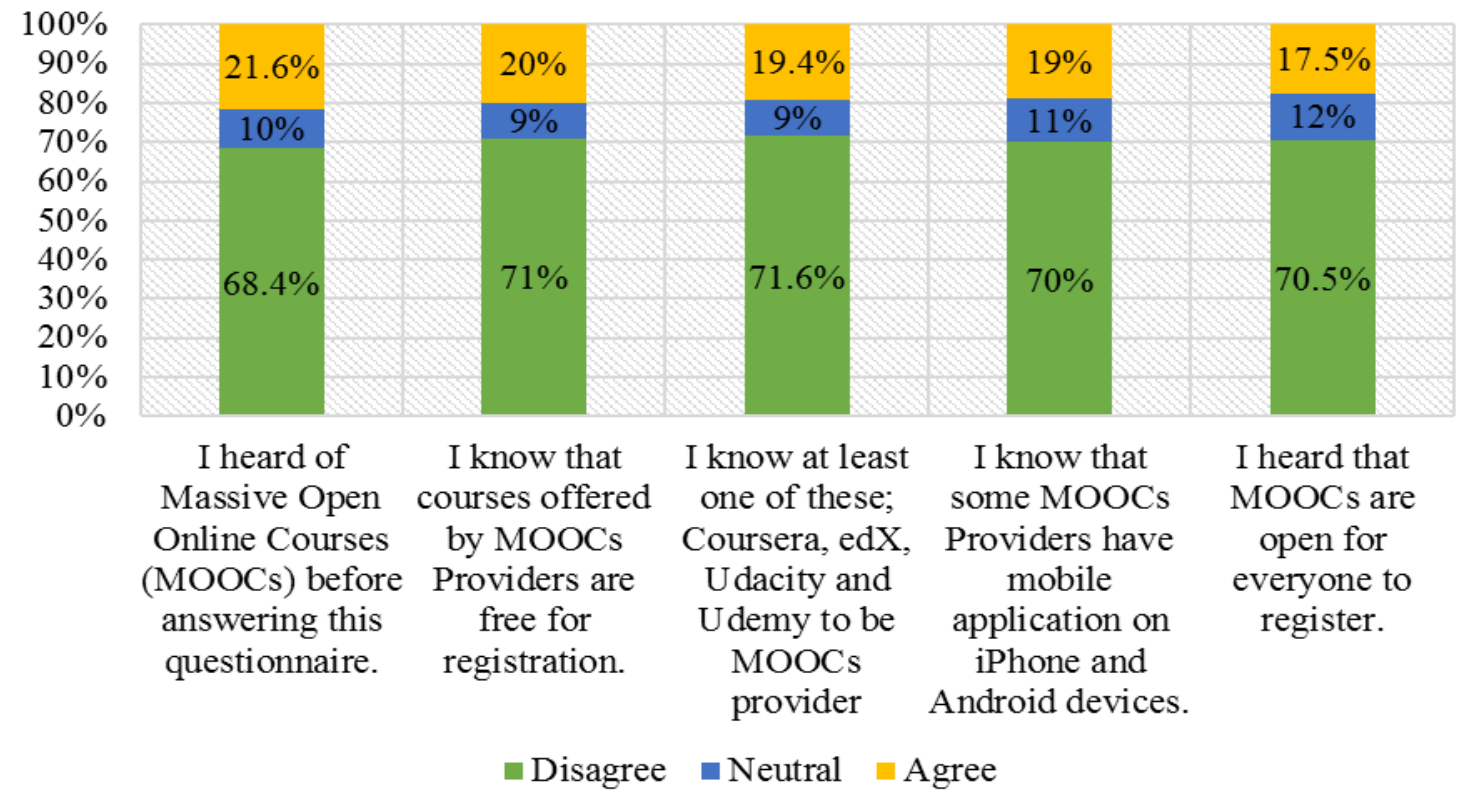

Figure 1. Awareness Knowledge of MOOCs

Most respondents had never heard of MOOCs prior to filling out the questionnaire (68.4\%); never heard of Coursera, edX, Udacity and Udemy as MOOC providers $(71.6 \%, \mathrm{n}=136)$; had no idea that MOOC courses are free $(71 \%, \mathrm{n}=135)$; and never knew that MOOCs are open for anyone to register $(70.5 \%, \mathrm{n}=134)$. Similarly, $70 \%(\mathrm{n}=133)$ never knew that some MOOC providers have their courses available on mobile applications like iPhone and Android devices.

Generally, the findings from all the above statements indicate that a majority of the respondents lack awareness knowledge about the existence of MOOCs and what it stands for. These are similar to the results found by Mamman (2016), in which he discovered a low awareness level of mobile application for online library accessibility among students of the same university. Again, a low awareness knowledge of stimulation games for e-learning and education among students was discovered by Păvăloiu, Neagu, and Drăgoi (2016).

It is important for students to be fully aware of MOOCs as this knowledge will assist in their learning pursuits. Students can gain knowledge from MOOCs and be better prepared for class. Awareness knowledge, again, is important as it helps prevent system underutilization among university students as this might be costly for higher learning institutions. However, very few students make use of MOOCs as they are unaware of these services.

\section{Procedural Knowledge of MOOCs}

The respondents' responses to the items showing their procedural knowledge of MOOCs are presented in Figure 2. Accordingly, a majority $(87.4 \%, \mathrm{n}=109)$ did not know how to create an account with any MOOC provider, or how to $\log$ in to attend classes $(61.1 \%, \mathrm{n}=116)$. In addition, 
$59.5 \%(\mathrm{n}=113)$ did not know how to download learning materials, and 58.4\% $(\mathrm{n}=111)$ did not know how to submit assignments in MOOCs. About 58\% $(\mathrm{n}=110)$ admitted not knowing how to enrol in any of the courses offered by the MOOCs providers.

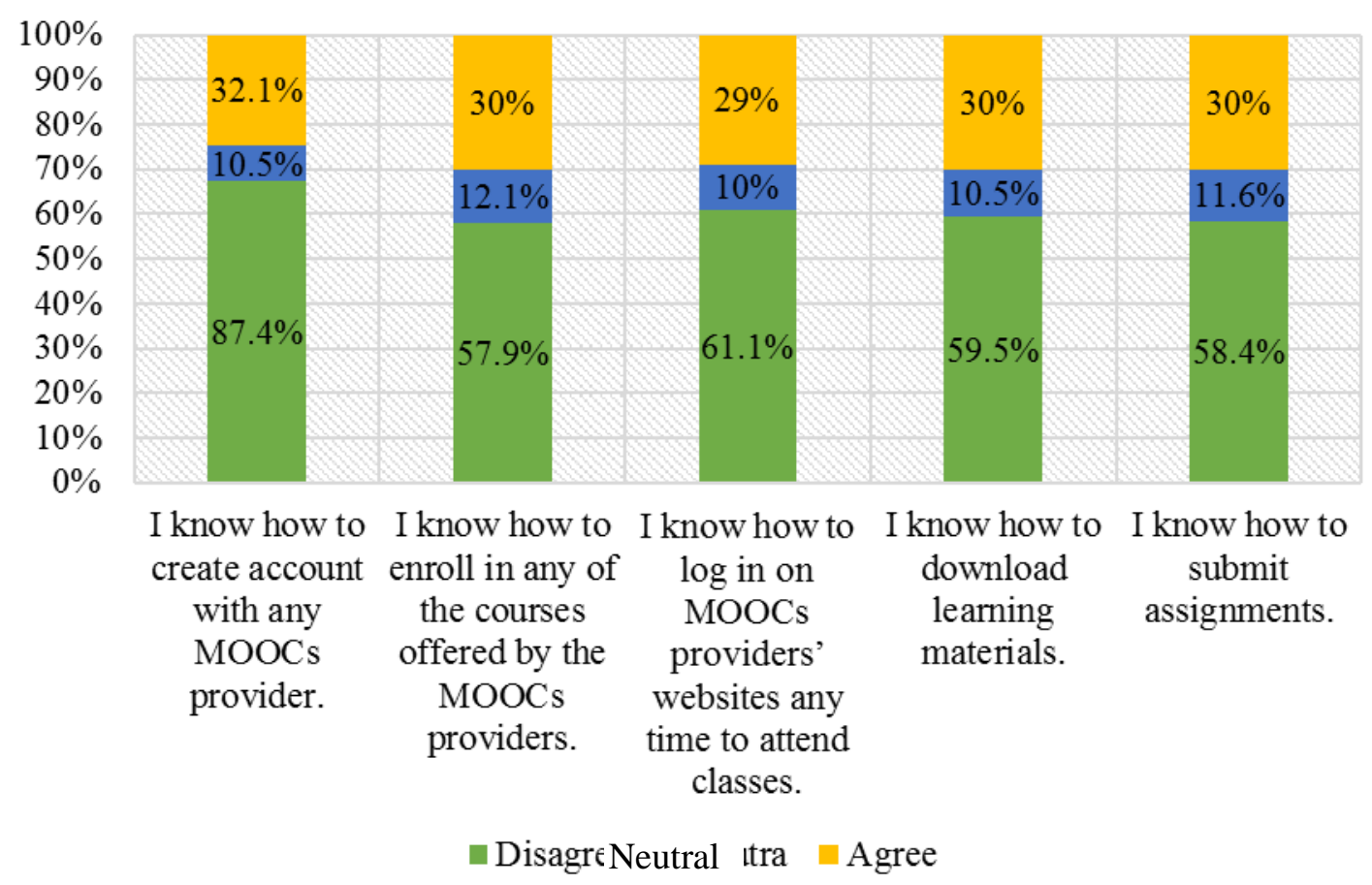

Figure 2. Procedural Knowledge of MOOCs

The findings generally indicate that a majority of the respondents do not have the procedural knowledge of MOOCs. However, most of the respondents are neutral about their knowing how to enrol in any of the courses offered by the MOOCs providers. These findings are consistent with previous studies such as Mamman (2016) who found out that a majority of university students have inadequate procedural knowledge of BookMyne, where most indicated they could not operate the system.

\section{Actual Usage of MOOCs}

Analysis of the respondents' responses regarding their level of usage of MOOCs was conducted. The findings are presented in Figure 3. 


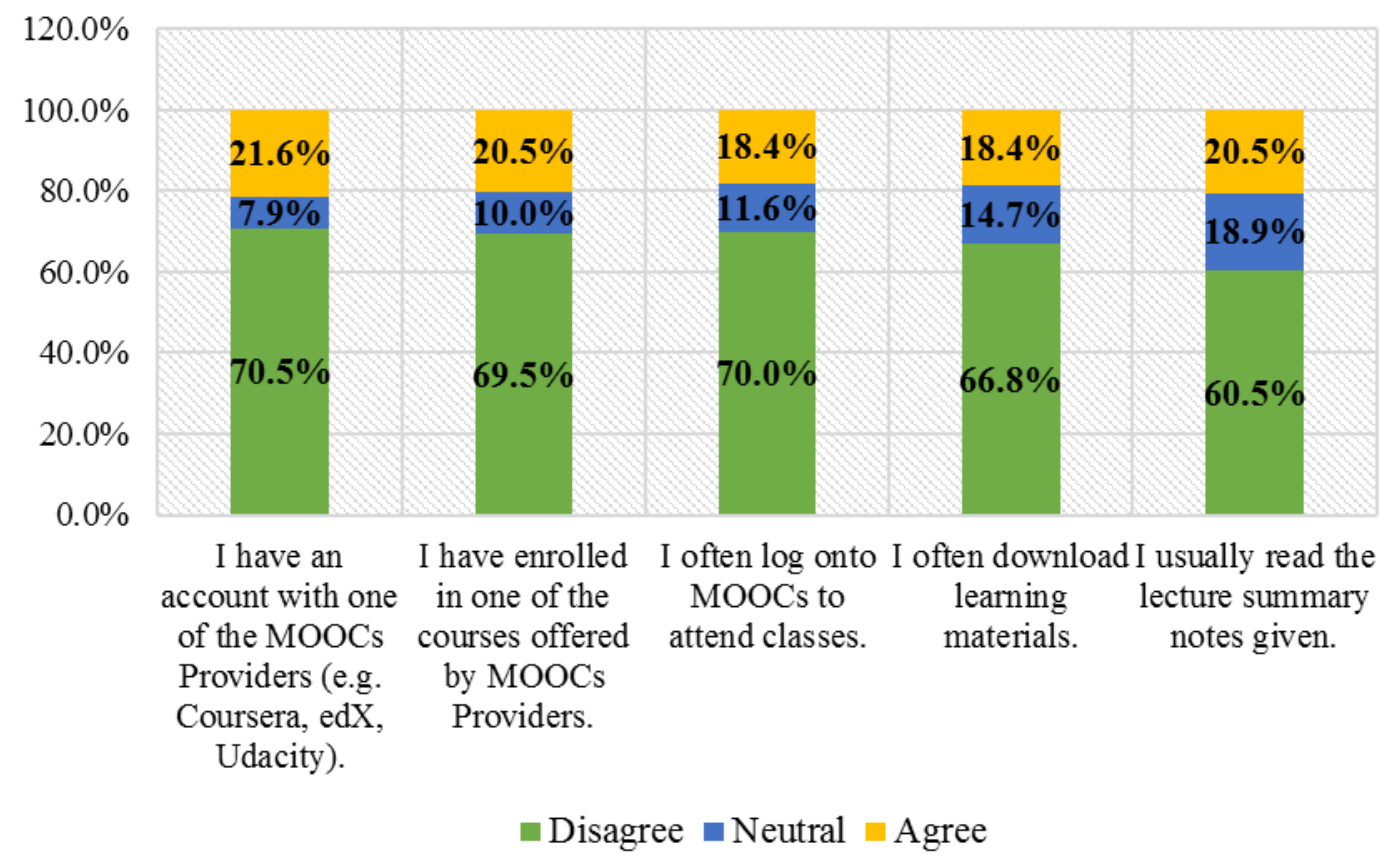

Figure 3. Actual Usage of MOOCs

The results show that a majority $(70.5 \%, \mathrm{n}=134)$ do not have an account with any of the MOOCs providers, therefore, it is understandable that the same percentage also indicated not logging in to attend or follow classes $(70 \%, \mathrm{n}=133)$. In addition, most respondents never enrolled in any of the courses offered by MOOC providers $(69.5 \%)$, or downloaded learning materials from their websites (66.8\%), or read the lecture summary notes provided by MOOC instructors (60.5\%).

The findings generally show a majority of postgraduate students not using MOOCs at all. Similar results were found in previous studies, e.g., Manyika, Chui, Bughin, Dobbs, Roxburgh, Sarrazin, Sands and Westergren (2013) who found low levels of e-learning content usage among employees.

\section{Perceived Usefulness of MOOCs}

The respondents' perceptions of the usefulness of MOOCs are presented in Figure 4. 


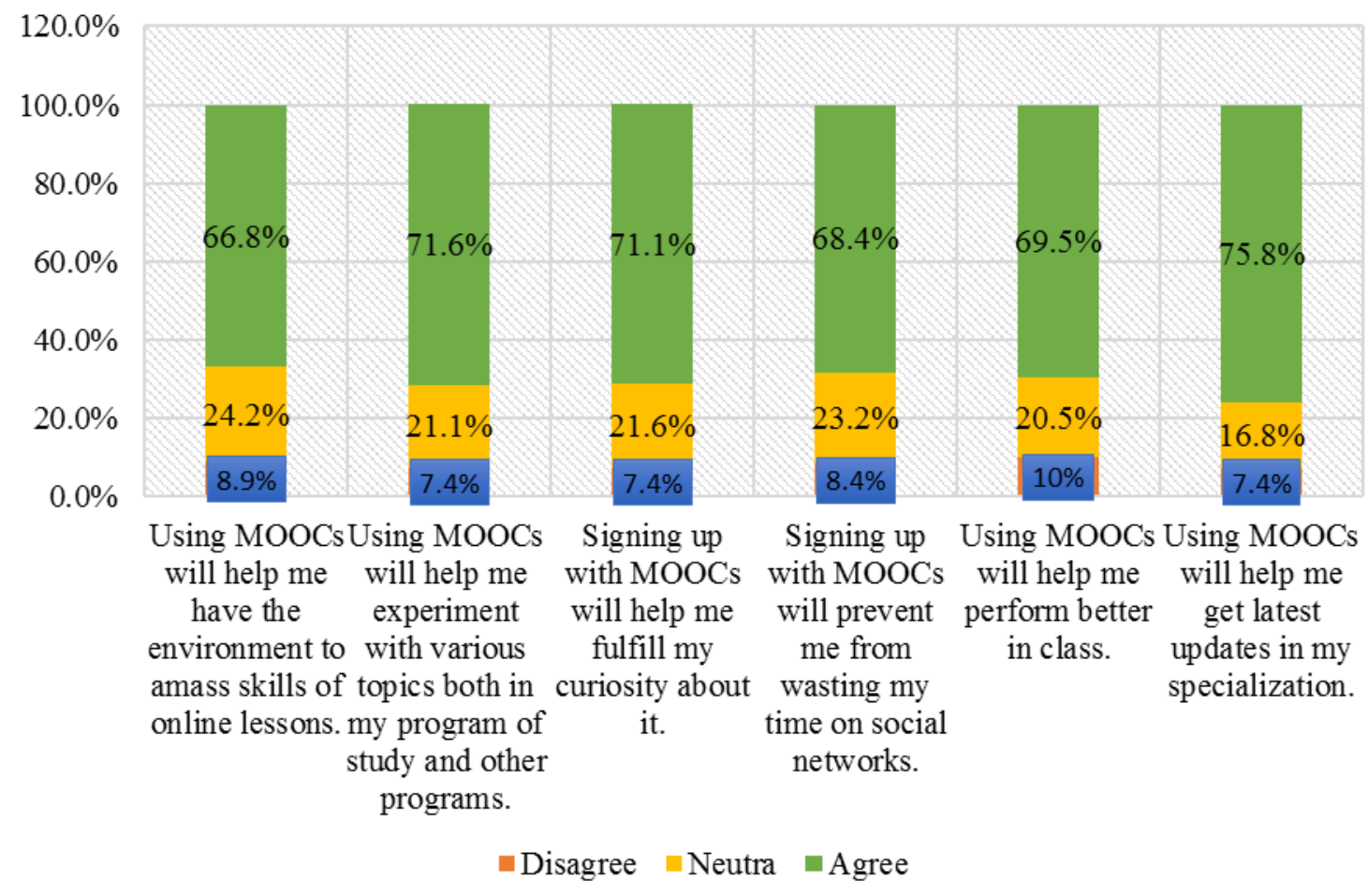

Figure 4. Perceived Usefulness of MOOCs

The results indicate that a majority of the respondents agreed that using MOOCs will help them (i) get latest updates in their areas of study $(75.8 \%, \mathrm{n}=144)$; (ii) explore various learning topics in and outside their programs of study $(71.6 \%, \mathrm{n}=136)$; (iii) fulfil their curiosity about learning (71.1\%; $\mathrm{n}=135)$; (iv) perform better in class (69.5\%; $\mathrm{n}=130$ ); and (v) amass skills for online lessons $(66.8 \%, \mathrm{n}=127)$.

It is clear that most respondents agreed with the educational values of MOOCs, seeing the platform as useful for learning. Similar findings as above can be found in the work of Soheila (2014) who discovered a strong relationship between intention to use and perceived usefulness. Thus, she concluded that the more teachers believe GeoGebra is useful and using it improves teachers' performance and enhances their effectiveness in teaching mathematics, the more likely they would utilize GeoGebra in their teaching. In other studies, perceived usefulness was discovered to play an important role in students' acceptance of e-learning (Amer, Ahmad \& Smedley, 2013), and exercised a significant influence on attitude towards using a learning management system (Juhary, 2014).

\section{Attitude towards MOOCs}

The respondents' attitude towards MOOCs is presented in Figure 5. 


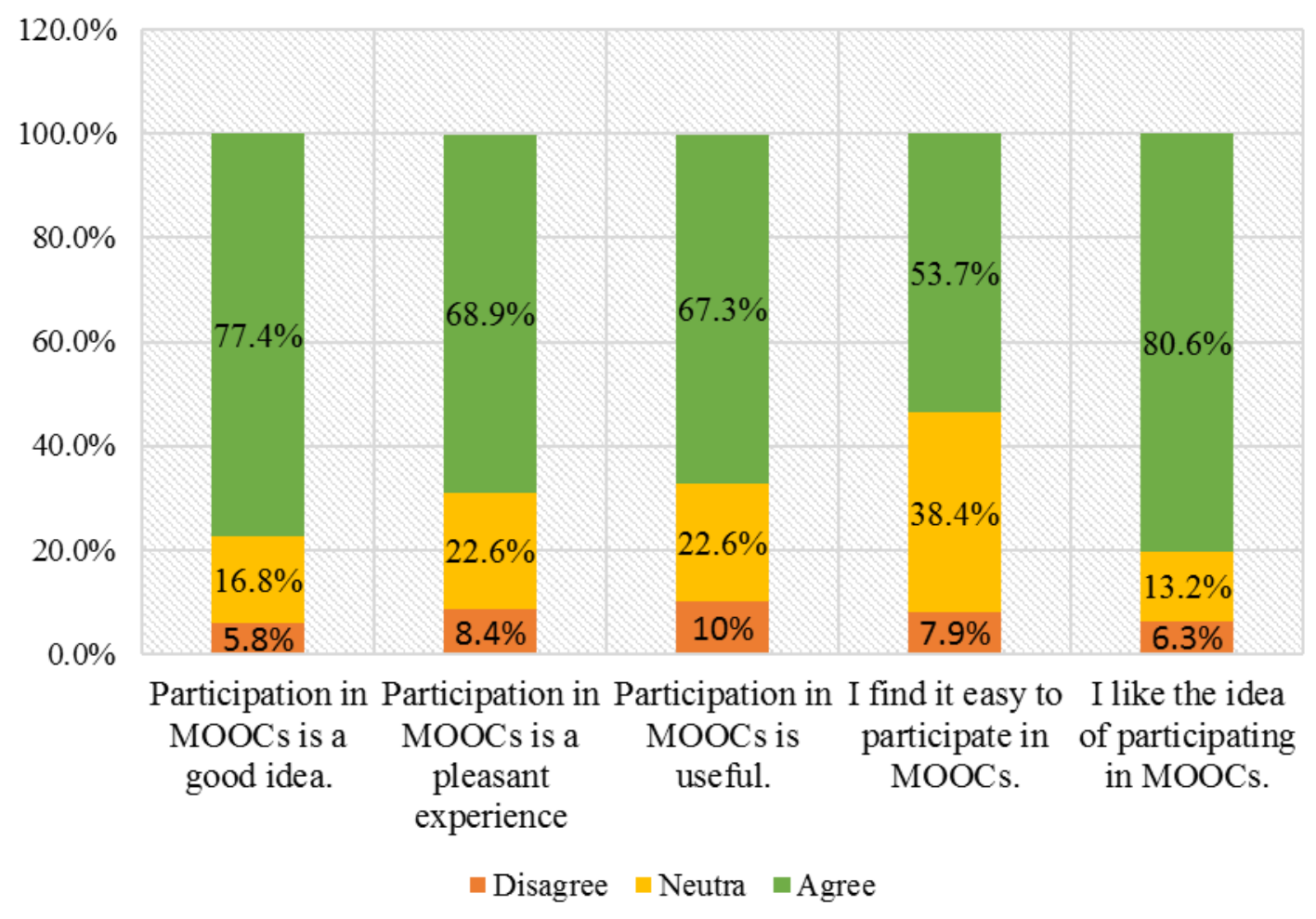

Figure 5. Attitude towards MOOCs

Although they are not familiar with MOOCs, a huge majority have a positive attitude towards it, perceiving participation in MOOCs as (i) a good idea (77.4\%; $\mathrm{n}=147$ ); (ii) a pleasant experience (68.9; $\mathrm{n}=131)$; and (iii) useful $(67.3 \% ; \mathrm{n}=128)$. More than $80 \%$ like the idea of taking MOOCs $(\mathrm{n}=153)$, although fewer respondents agreed it would be easy to do so $(53.7 \% ; \mathrm{n}=102)$.

The general findings indicate that most postgraduate students responded favourably to MOOCs with a positive attitude. These findings are consistent with that of Hong (2015) who identified students as having a positive attitude and persistence in online learning. Another study revealed that perceived usefulness and perceived ease of use were strong and statistically significant predictors of attitude towards using Moodle (Pan, 2003). Additionally, some studies have pointed out the existence of a significant relationship between perceived usefulness and perceived ease of use of Web 2.0 technologies (Quadri et al., 2014).

\section{Intention to Use MOOCs for Academic Purposes}

This study further seeks to establish whether the respondents have the intention to use MOOCs for academic purposes. The results, presented in Figure 6, illustrate that a majority of the respondents $(87.4 \%, \mathrm{n}=166)$ expressed an intention to use MOOCs to increase the quality of their current study. About $76.3 \%(\mathrm{n}=145)$ said they would explore the courses available in MOOCs that are related to their study after creating an account with a selected provider. On top of that, $75.3 \%(\mathrm{n}=$ 143) said they would use MOOCs to broaden their understanding of their area of study. 


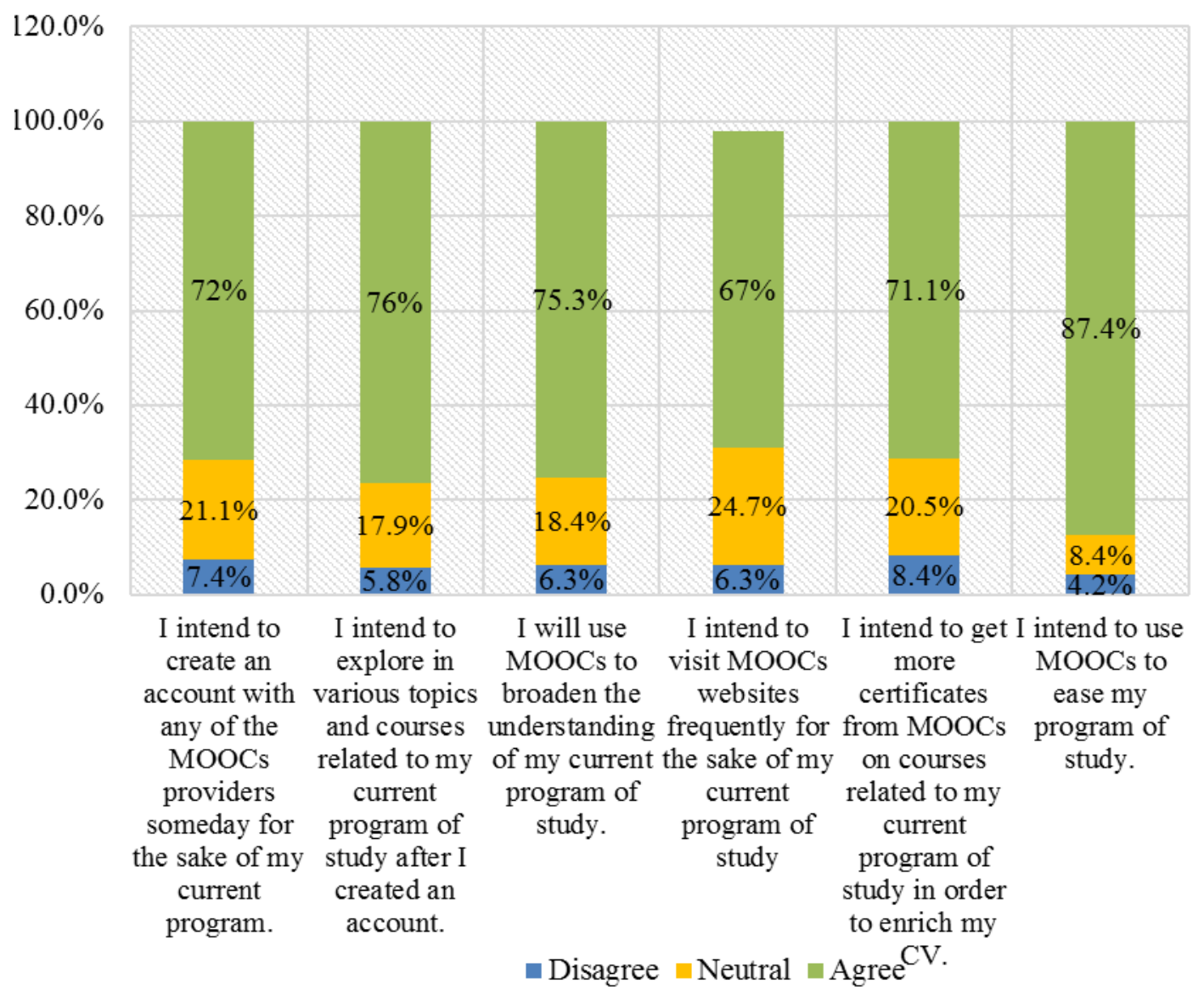

Figure 6. Intention to Use MOOCs for Academic Purposes

The results further show that $71.4 \%(\mathrm{n}=136)$ expressed an interest to create an account with a MOOC provider to further their learning, while $71.1 \%(\mathrm{n}=135)$ wished to obtain more certificates in MOOCs on courses related to their current area of study in order to enrich their curriculum vitae. Quite a big number is interested in visiting MOOC websites frequently for learning $(66.9 \% ; \mathrm{n}=$ 127).

Overall, from the findings in Figure 6, it can be observed that a majority of the respondents have an expressed intention to use MOOCs for learning or various other academic purposes. Similar findings to those above can be found in previous studies that discovered high levels of students' intention to use mobile applications for learning and to access online library services (Mamman, 2016; Clack \& Pan, 2014). However, research findings in this area have not been consistent, as a lack of adequate intention to use e-learning and Internet facilities was detected among school students (Eke, 2011; Kasikitsakumpmphon \& Vanijja, 2013). The results of this study have essentially shown much enthusiasm among the postgraduate students of the selected university to engage in MOOCs activities despite their inadequate levels of awareness of the technology. Thus, the need arises for the university authorities to devise ways and means of creating more awareness about MOOCs among its postgraduate student population, and encouraging them to utilise these services for a more enhanced learning experience. 


\section{RECOMMENDATIONS}

This study has found a low level of awareness and usage of MOOCs among postgraduate university students. This should not be the case as MOOCs are created for tertiary learning. Thus, the university authorities and e-learning committees should organise workshops and seminars so students will be educated on the importance of MOOCs to improve their awareness and usage level of the technology.

For students to feel the comfort and benefits of online learning such as MOOCs, their confidence level in using the technology needs to be increased. As such, the basic skills needed to be familiar with MOOCs and achieve one's aim has to be first provided during workshops on this technology as well as through booklets, posters and any other medium of creating awareness of the technology.

Again, each faculty should encourage lecturers to flip their classrooms with MOOC technologies and learning materials for effective utilization of the system so students will really feel the need to utilise these services that come at less or no cost. Also, the Education Ministry should take a crucial step in initiating awareness about Open Learning to the public and private institutions in Malaysia.

\section{CONCLUSION}

The potentials of using MOOC technologies are real and significant, given that they provide access to dynamic information on students' programmes of study. At a time in the twenty-first century where new instructional technologies are on ascendancy, students need to embrace these technologies with the opportunities they come with. MOOCs seem to be a significant platform in this circumstance for the provision of free educational services using modern technologies. The familiarity with MOOCs and continuous usage of the platform should equip postgraduate students with lifelong learning capabilities so important for 21 st century higher education.

\section{REFERENCES}

Alobiedat, A. \& Saraierh, R. (2010). The student's attitude toward use platform as learning resources at university of granada. Journal of Review of European Studies, 2(2), 236-244.

Alraimi, K. M., Zo, H. \& Ciganek, A. P. (2015). Understanding the MOOCs continuance: The role of openness and reputation. Computers \& Education, 80, 28-38. http://doi.org/10.1016/j. compedu.2014.08.006

Amer, A., Ahmad, A. \& Smedley, J. (2013). Exploring students' acceptance of e-learning using Technology Acceptance Model in Jordanian universities Amer Al- Adwan Applied Science University, Jordan Ahmad al- Adwan Cardiff Metropolitan University, UK Jo Smedley, 9(2), 4-18. 
Amrang, N. A. H. (2016). Massive open online courses a means of free higher education. Retrieved from MalaysiaKini: http://www.malaysiakini.com/letters/358738

Chen, X., Barnett, D. R. \& Stephens, C. (2013). Fad or future: The advantages and challenges of Massive Open Online Courses (MOOCs). R2P - Research-to-Practice Conference in Adult and Higher Education. Retrieved from https://www.lindenwood.edu/r2p/docs/ Chen BarnettStephens.pdf

Chen, G. \& Chiu, M.M. (2008). Online discussion processes: Effects of earlier messages' evaluations, knowledge content, social cues and personal information on later messages. Computers \& Education, 50, 678-692. doi: 10.1016/j.compedu.2006.07.007

Chenda Hong, M.S. (2015). Predictors of attitudes toward the use of moodle for learning english in a blended learning environment in Cambodia (Doctoral dissertation, Northern Illinois University). Retrieved from ProQuest Dissertations and Theses database. (UMI No. 1591011).

Clark, T. (2013). The advance of the MOOCs (massive open online courses) the impending globalization of business education? Journal of Education and Training, 55(4/5), 403-413.

Clack, J. \& Pan, R. (2014). Strategic mobile learning development: The place of library apps and options for creating them. Leadbharlann UCD, UCD Library Project Report. Retrieved from www.ucd.ie/t4cms/ANLTC_SWETS\%20REPORT\%202012.pdf.

Davis, F. D. (1989). Perceived usefulness, perceived ease of use, and user acceptance of information technology. MIS Quarterly, 13(3), 319-340.

Eke, H. N. (2011). Modeling LIS students' intention to adopt e-learning: A case from university of Nigeria, Nsukka. Library Philosophy and Practice. Retrieved from http://www.webpages. uidaho.edu/ mbolin/helen-eke.pdf

Hew, K. F. \& Cheung, W. S. (2014). Students' and instructors' use of massive open online courses (MOOCs): Motivations and challenges. Educational Research Review, 12(2014), 45-58.

Hu, P. J., Chau, P. Y. K., Liu Sheng, O. R. \& Kar Yan, T. (1999). Examining the Technology Acceptance Model Using Physician Acceptance of Telemedicine technology. Journal of Management Information Systems, 16(2), 91-112.

Juhary, J. (2014). Perceived Usefulness and Ease of Use of the Learning Management System as a Learning Tool. International Education Studies, 7(8), 23-34. http://doi.org/10.5539 /ies.v7n8p23

Kasikitsakunphon, S. \& Vanijja, V. (2013). Factors influencing the intention to use VoIP service by consumers in Thailand. International Conference on ICT Convergence (ICTC), 9971002. doi:10.1109/ICTC.2013.6675539 
Lin, S.Y. \& Overbaugh, R.C. (2009). Computer-mediated discussion, self-efficiency and gender. In British Journal of Educational Technology, 40(6), 999-1013. doi:10.1111/j.14678535.2008. 00889.x

Mamman, B. (2016). Awareness and procedural knowledge as predictors of IIUM undergraduate students' intention to use Bookmyne: An exploratory study (Unpublished master's thesis, International Islamic University, Kuala Lumpur, Malaysia).

Mat-jizat, J. E., Samsudin, N., Yahaya, R., Pendidikan, U. \& Idris, S. (2014). Higher education institutions (hei) students take on MOOC: Case of Malaysia, (CELDA), 2011-2014.

McAuley, A., Stewart, B., Siemens, G. \& Cormier, D. (2010). The MOOC model for digital practice (Unpublished manuscript, University of Prince Edward Island). Retrieved from http://www.elearnspace.org/Articles/MOOC_Final.pdf

Pan, C.C. (2003). System use of WeBCT in the light of the technology acceptance model: A student perspective (Doctoral dissertation, University of Central Florida). Retrieved from ProQuest Dissertations and Theses database. (UMI No. 3094813).

Păvăloiu, I., Neagu, A. \& Drăgoi, G., (2016). IBM innovation business simulation games for elearning and education. The $8^{\text {th }}$ International Scientific Conference eLearning and software for Education, 90-96. http://doi.org/10.5682/2066-026X-12-171

Quadri, L. K., Committee, R., Chairperson, C., Faculty, E., Member, C., Faculty, E. \& Riedel,E. (2014). Teachers' perceptions and attitudes toward the implementation of Web 2.0 tools in secondary education (Doctoral dissertation, Walden University). (UMI No. 3611469).

Raman, A. (2011). The usage of technology among education students in University Utara Malaysia: An application of extended Technology Acceptance Model. International Journal of Education and Development using Information and Communication Technology, 7(3), 4-17.

Connectivist learning theory (2012, January 19). Siemens, G. In Wikipedia reetrieved from the foundation Wiki: http://p2pfoundation.net/Connectivist_Learning_Theory_Siemens

Soheila, A. (2014). Malaysian teachers' intention to use GeoGebra in teaching Mathematics in the classrooms based on their perceived usefulness, ease of use, and current competencies of using GeoGebra (Unpublished master's thesis, International Islamic University, Kuala Lumput, Malaysia).

Taylor, S. \& Todd, P. A. (1995). Understanding information technology usage: A test of competing models. Information Systems Research, 6(2), 144-176.

Venkatesh, V. (2000). Determinants of perceived ease of use: Integrating control, intrinsic motivation, and emotion into the Technology Acceptance Model. Information systems research, 11(4), 342. 